\title{
The Influence of Sodium Tungstate Concentration on the Electrode Reactions at Iron-Tungsten Alloy Electrodeposition
}

\author{
Stanislav Belevskii ${ }^{1}$, Serghei Silkin ${ }^{2,3}$, Natalia Tsyntsaru ${ }^{1,4}$, Henrikas Cesiulis ${ }^{4,5, * \mathbb{C}}$ and Alexandr Dikusar ${ }^{1,2, *}$ \\ 1 Institute of Applied Physics, MD-2028 Chisinau, Moldova; stas.ch_fzy@bk.ru (S.B.); \\ natalia.tintaru@chf.vu.lt (N.T.) \\ 2 Laboratory "Electrochemical Fabrication", Transnistrian State University Named after T.G. Shevchenko, \\ MD-3300 Tiraspol, Moldova; longamin@mail.ru \\ Department of Chemistry, Kostroma State University, 156005 Kostroma, Russia \\ 4 Department of Physical Chemistry, Vilnius University, LT-03225 Vilnius, Lithuania \\ 5 JSC “Elektronikos perdirbimo technologijos", LT-06140 Vilnius, Lithuania \\ * Correspondence: henrikas.cesiulis@chf.vu.lt (H.C.); alexandr.dikusar@ifa.md (A.D.)
}

Citation: Belevskii, S.; Silkin, S.;

Tsyntsaru, N.; Cesiulis, H.; Dikusar, A.

The Influence of Sodium Tungstate

Concentration on the Electrode

Reactions at Iron-Tungsten Alloy

Electrodeposition. Coatings 2021, 11,

981. https://doi.org/10.3390/

coatings11080981

Academic Editor: Elena Pikalova

Received: 23 July 2021

Accepted: 12 August 2021

Published: 18 August 2021

Publisher's Note: MDPI stays neutral with regard to jurisdictional claims in published maps and institutional affiliations.

Copyright: (c) 2021 by the authors. Licensee MDPI, Basel, Switzerland. This article is an open access article distributed under the terms and conditions of the Creative Commons Attribution (CC BY) license (https:// creativecommons.org/licenses/by/ $4.0 /)$

\begin{abstract}
The investigation of Fe-W alloys is growing in comparison to other $\mathrm{W}$ alloys with iron group metals due to the environmental and health issues linked to $\mathrm{Ni}$ and $\mathrm{Co}$ materials. The influence of $\mathrm{Na}_{2} \mathrm{WO}_{4}$ concentration in the range 0 to $0.5 \mathrm{M}$ on bath chemistry and electrode reactions on $\mathrm{Pt}$ in Fe-W alloys' electrodeposition from citrate electrolyte was investigated by means of rotating disk electrode (RDE) and cyclic voltammetry $(\mathrm{CV})$ synchronized with electrochemical quartz crystal microbalance (EQCM). Depending on species distribution, the formation of Fe-W alloys becomes thermodynamically possible at potentials less than $-0.87 \mathrm{~V}$ to $-0.82 \mathrm{~V}$ (vs. $\mathrm{Ag} / \mathrm{AgCl}$ ). The decrease in electrode mass during cathodic current pass in the course of $\mathrm{CV}$ recording was detected by EQCM and explained. The overall electrode process involving Fe-W alloy formation may be described using formalities of mixed kinetics. The apparent values of kinetic and diffusion currents linearly depend on the concentration of $\mathrm{Na}_{2} \mathrm{WO}_{4}$. Based on the values of partial currents for $\mathrm{Fe}$ and $\mathrm{W}$, it was concluded that codeposition of Fe-W alloy is occurring due to an autocatalytic reaction, likely via the formation of mixed adsorbed species containing $\mathrm{Fe}$ and $\mathrm{W}$ compounds or nucleation clusters containing both metals on the electrode surface.
\end{abstract}

Keywords: Fe-W alloys; induced codeposition; electrode reaction; distribution of species; EQCM; rotating disk electrode

\section{Introduction}

Considering electrolyte chemistry is an essential step towards the understanding of phenomena involved in the electrodeposition of a target material under optimal deposition conditions. This knowledge has a direct impact on achieving better control over the deposits growth and thus on desired characteristics. It is particularly significant in the case of an electrodeposition of iron group metal alloys with refractory metals because they are formed via an induced codeposition mechanism. This mechanism is still under consideration, and was reviewed elsewhere [1-3]. Alloys have sustained scientific interest over decades because, depending on the targeted application, they can be applied as resistant to wear and corrosion, and catalytic, magnetic materials that complement their nanocrystalline structure $[1,2,4,5]$. Moreover, the versatile spectrum of the application of these alloys is owing to the possibility to obtain such materials in the form of coatings/films, as well as quasi-one-dimensional structures (nano-wires, -rods and -ribbons) [6,7].

Recently, electrochemical studies were concentrated preferentially on Fe alloys, whereas the use of $\mathrm{Ni}, \mathrm{Co}$ and their salts were discouraged due to environmental and health issues. Thus, Fe-W alloys as "eco-friendly" deposits are investigated for multipurpose applications: protective coatings [8], recording media [9,10], catalysts [11], and fuel cells [12]. 
In order to approach the electrode potentials of two different metals and to avoid precipitation of sparingly soluble Fe-, Co- and Ni-tungstates and -hydroxides, complexing agents are added to the electrolyte. One of the most common complexing agents that have been used for electrodeposition of Fe-W [13-16], Co-W [17], and Ni-W [18,19] alloys are citric acid and citrate salts. The presence of citrate ligands leads to concomitant redistribution of various metal poly- and hydroxo-species, which are formed in the bath $[2,13,20,21]$. The assessment of species distribution could also provide insight into the bath stability and the deposition mechanism by correlating the theoretical and the experimental data. Moreover, the evaluation of species distribution could help understand the compositional variation within the coating thickness and increase (or decrease) in cathodic current efficiency of the process [22]. Moreover, heterometallic species with enhanced molecular mass can be formed in the electrolyte $[23,24]$, whose stability constants are not yet identified. Furthermore, depending on $\mathrm{pH}$ and electrodeposition potential, the specific adsorption of citrate anions and the catalytic transformation of citrate accompanied by decarboxylation and electron transfer to the electrode surface followed by further reduction of the adsorbed species has been observed [25,26].

In the case of Fe-W electrodeposition, the bath chemistry is even more complicated in comparison to $\mathrm{Co}-\mathrm{W}$ or $\mathrm{Ni}-\mathrm{W}$ alloys plating because iron chemically exists in two oxidation states, $\mathrm{Fe}(\mathrm{II})$ and $\mathrm{Fe}(\mathrm{III})$, which readily transfer from one oxidation state to another. Therefore, Fe(II) can be oxidized by dissolved oxygen, because the standard potential for oxygen reduction is more positive than in the case of $\mathrm{Fe}^{3+}$ reduction to $\mathrm{Fe}^{2+}$ $\left(E_{\mathrm{O}_{2} / \mathrm{H}_{2} \mathrm{O}}^{0}=1.23 \mathrm{~V}, E_{\mathrm{Fe}^{3+} / \mathrm{Fe}^{2+}}^{0}=0.77 \mathrm{~V}\right.$, vs. SHE) [27]. The presence of a complexing agent can only inhibit this process, but not prevent it. Therefore, in order to prolong the lifetime of Fe(II)-electrolytes, some reducing agents are often used [28]. But, those compounds can affect the bath chemistry and coatings' properties in a rather unpredictable way.

Moreover, the induced codeposition is a rather complex process. The initially presented or formed species can adsorb in the coatings, leading to incorporation of oxygen, carbon, and hydrogen in top layers of the deposits [29]. This incorporation in turn can affect "surface-dependent" properties (e.g., microhardness, corrosion rate) of obtained alloys. Thus, it was revealed that microhardness and corrosion resistance at fixed composition of an electrolyte, $\mathrm{pH}$, current density, and potential are dependent on: (a) the deposition surface area at a fixed volume of an electrolyte; (b) the volume of electrolyte at constant surface area [30]. This, in turn, leads to a need to control common technological parameters used in electrochemical technology and, e.g., the volume current density while transferring a technology from the laboratory to industrial scale.

The peculiarities mentioned above lead to a need for a detailed investigation of targeted alloy deposition even in the case of simple as possible bath composition., e.g., by using controlled hydrodynamic conditions [31,32] or/and complementary electrochemical techniques (quartz crystal microbalance coupled with electrochemical techniques) [33,34].

In this study, the influence of sodium tungstate concentration on bath chemistry and on the electrode reactions at Fe-W alloy electrodeposition from citrate electrolyte was investigated in dependence on the electrode potential using rotating disk electrode (RDE), as well as cyclic voltammetry $(\mathrm{CV})$, synchronized with the electrochemical quartz crystal microbalance (EQCM).

\section{Materials and Methods}

\subsection{Materials}

The electrodeposition of Fe-W alloys was carried out at $\mathrm{pH} 6.9$ from a citrate bath containing (mol/L): $\mathrm{FeSO}_{4}-0.2, \mathrm{C}_{6} \mathrm{H}_{8} \mathrm{O}_{7}$ (citric acid)-0.17, $\mathrm{Na}_{3} \mathrm{C}_{6} \mathrm{H}_{5} \mathrm{O}_{7}$ (sodium citrate)-0.33 and various concentrations of $\mathrm{Na}_{2} \mathrm{WO}_{4}$ (sodium tungstate) ranged from 0 to $0.5 \mathrm{~mol} / \mathrm{L}$. All chemicals were of analytical grade and the aqueous solutions were prepared with distilled water. The electrodeposition of pure iron was carried out from electrolytes that contained the same components but without sodium tungstate. 


\subsection{Electrodeposition and Electrochemical Measurements}

The potentiostatic mode (a potentiostat/galvanostat Autolab PGSTAT30) was used for the electrodeposition of alloys on a Pt rotating disk electrode (RDE) with a diameter of $3 \mathrm{~mm}$ and a rotation speed of 200-2000 rpm (20.94 to $209.43 \mathrm{rad} / \mathrm{s})$. The electrodeposition on RDE was carried out with separated anode and cathode spaces (salt bridge based on a saturated solution of $\mathrm{Na}_{2} \mathrm{SO}_{4}$ ) in a three-electrode system with $\mathrm{Pt}$ as counter and saturated $\mathrm{Ag} / \mathrm{AgCl}$ as reference electrodes. All potentials were recorded with respect to this reference electrode. The deposition potential was varied from $-0.2 \mathrm{~V}$ to $-1.1 \mathrm{~V}$ under thermostatic conditions of $80^{\circ} \mathrm{C}$.

The chemical composition of the as-electrodeposited Fe-W alloys was examined with energy dispersive X-ray fluorescence (ED-XRF) elemental analyzer (Xenemetrix, Migdal Haemek, Israel). Based on the chemical composition of the obtained alloys, the current efficiency (CE) was calculated according to the Faradays' law as it is described in [11]:

$$
C E(\%)=\frac{F \cdot m}{I t}\left(\frac{x_{\mathrm{Fe}} n_{\mathrm{Fe}}}{M_{\mathrm{Fe}}}+\frac{x_{\mathrm{W}} n_{\mathrm{W}}}{M_{\mathrm{W}}}\right) \times 100 \%,
$$

where $F$ is the Faraday constant (in C. $\mathrm{mol}^{-1}$ ); $m$ is the mass of deposited alloy (in g); $x_{\mathrm{Fe}}$ and $x_{\mathrm{W}}$ is the weight fraction of iron and tungsten in the alloy, respectively; $n_{\mathrm{Fe}}, n_{\mathrm{W}}$ is the electron number for Fe and $\mathrm{W}$, respectively; $M_{\mathrm{Fe}}, M_{\mathrm{W}}$ is the molecular weight of iron and tungsten (in $\mathrm{g} \cdot \mathrm{mol}^{-1}$ ); $I$ is the total current flowing through the solution (in A); $t$ is the electrodeposition time (in sec). If potentiostatic mode is employed, it is convenient to use the electric charge, $Q$, passed during electrodeposition $(Q=I t)$.

The current efficiency was determined on the stationary copper plate working electrode of $2 \mathrm{~cm}^{2}$. Thereupon, a nickel seed layer was electrodeposited onto a steel substrate from the nickel-plating electrolyte containing $240 \mathrm{~g} / \mathrm{L} \mathrm{NiCl}_{2} \cdot 6 \mathrm{H}_{2} \mathrm{O}+80 \mathrm{~g} / \mathrm{L} \mathrm{HCl}$ for $1 \mathrm{~min}$ at $30 \mathrm{~mA} / \mathrm{cm}^{2}$.

Electrochemical quartz crystal microbalance (EQCM) was used to study electrodeposition of Fe-W alloys dependent on potential from the same electrolyte and working temperature as described above. The cyclic voltammetry was recorded in the potential range $-0.2 \mathrm{~V}$ to $-1.2 \mathrm{~V}$ at a scan rate of $20 \mathrm{mV} / \mathrm{s}$ in a three-electrode cell having a volume of $50 \mathrm{~mL}$. Quartz resonator electrodes coated with $\mathrm{Pt}\left(R_{\mathrm{a}}=0.06 \mu \mathrm{m}\right.$, working area $\left.=0.196 \mathrm{~cm}^{2}\right)$ as working electrode, saturated $\mathrm{Ag} / \mathrm{AgCl}$ as reference electrode and graphite electrode as counter one were used. Electrochemical measurements were performed using SP-150 potentiostat (Bio-Logic Science Instruments, Seyssinet-Pariset, France) and QCM922 quartz microbalance (SEIKO EG\&G, Tokyo, Japan).

\subsection{Calculation of Species Distribution}

Maple6 (Waterloo Maple Software Inc., Waterloo, Canada) was applied for the calculation of species distribution. The general principle to create and solve the system of equations was kept in force. Namely, the number of variables has to be equal to the number of equations. The system of equations was comprised of the following types of equations: (i) the equilibrium constants for all compounds added to or formed in the solutions: citric acid deprotonation, $\mathrm{Fe}(\mathrm{II})$ and $\mathrm{Fe}(\mathrm{III})$ hydrolysis, $\mathrm{Fe}(\mathrm{II}), \mathrm{Fe}(\mathrm{III})$, and $\mathrm{WO}_{4}{ }^{2-}$ complexes with citrate; (ii) the mass balance equation for each salt used for solution preparation $\left(\mathrm{FeSO}_{4}\right.$, $\mathrm{Na}_{2} \mathrm{WO}_{4}$, trisodium citrate plus citric acid) as a sum of concentrations of all corresponding species in the equilibrium mixture; (iii) the charge balance equation:

$$
\sum n_{i}\left[\mathrm{Cat}^{n+}\right]-\sum\left|m_{i}\right|\left[\mathrm{An}^{m-}\right]=0,
$$

where "Cat" and "An" denote concentrations of positively and negatively charged species in the solution, respectively.

Citric acid is considered a four-protonated acid. The preliminary calculation showed that the concentrations of $\mathrm{Fe}(\mathrm{II})$ and $\mathrm{Fe}(\mathrm{III})$ polynucleous hydroxo-complexes under the 
studied conditions are small compared to other species including Fe(II) and Fe(III); therefore, their formation was not considered in these calculations.

\section{Results and Discussions}

\subsection{Chemical Equilibrium in the Bath}

The electrodeposition of Fe-based alloys is commonly carried out from electrolytes containing Fe(II) compounds, a source of iron [35-37]. However, the key feature of electrolytes based on Fe(II) compounds is their instability because they readily oxidize to Fe(III) in the presence of dissolved oxygen even at the solution preparation stage. The Fe(II) oxidation rate increases markedly in the presence of citrates [30]. The spontaneous reaction of this process can be expressed as:

$$
4 \mathrm{Fe}^{2+}+\mathrm{O}_{2}+4 \mathrm{H}^{+}=4 \mathrm{Fe}^{3+}+2 \mathrm{H}_{2} \mathrm{O},
$$

The calculated equilibrium constant of this reaction is quite large $K_{e q}=1.3 \times 10^{31}$ [20], i.e., an equilibrium is shifted toward products. Therefore, both Fe(II) and Fe(III) complexes are forming in the solution after $\mathrm{FeSO}_{4}$ had been dissolved. At $\mathrm{pH} 7$, the percentage of Fe(III) species could reach $\sim 95 \%$ [2,20,38]. Therefore, knowledge on electrolyte behaviour and species distribution plays an important role in understanding the thermodynamics and kinetics of electrode processes, e.g., the assessment of reversible reduction potentials of ions in the complex solutions as well as the rate of reduction to metallic state [39]. Moreover, the concentrations of species, including concentrations of "free" ions such as $\mathrm{Fe}^{2+}, \mathrm{Fe}^{3+}$, $\mathrm{WO}_{4}{ }^{2-}$ (potential-determining ions) depend on a whole composition of the solution. After the dissolution of $\mathrm{FeSO}_{4}, \mathrm{Na}_{2} \mathrm{SO}_{4}$, sodium citrate, and citric acid, a number of $\mathrm{Fe}(\mathrm{II})$ and $\mathrm{Fe}(\mathrm{III})$ complexes with hydroxo- and citrate- groups and mixed $\mathrm{WO}_{4}$-citrate complexes can form [2,20]. There were at least 29 various species at concentrations $>10^{-15} \mathrm{M}$ formed in the solutions at $\mathrm{pH} 6.9$, which were taken into account for the calculation of species distribution (Table 1). The calculated distribution of main species in the studied solutions as a function of $\mathrm{Na}_{2} \mathrm{WO}_{4}$ concentration is shown in Figure 1.

Table 1. The list of species formed in the solution and considered for calculations at $\mathrm{pH} 6.9$ after dissolving $\mathrm{FeSO}_{4}, \mathrm{Na}_{2} \mathrm{WO}_{4}$, sodium citrate and citric acid.

\begin{tabular}{|c|c|}
\hline Species Containing Citrate: & Fe(III) Species: \\
\hline $\mathrm{HCit}^{3-}, \mathrm{H}_{2} \mathrm{Cit}^{2-}, \mathrm{H}_{3} \mathrm{Cit}^{-}, \mathrm{H}_{4} \mathrm{Cit}$ & $\mathrm{Fe}^{3+}, \mathrm{Fe}(\mathrm{OH})^{2+}, \mathrm{Fe}(\mathrm{OH})_{2}{ }^{+}, \mathrm{Fe}(\mathrm{OH})_{3}, \mathrm{FeCit}^{-}$, FeHCit \\
\hline Species Containing Tungstate: & Tungstate-Citrate Species: \\
\hline $\mathrm{WO}_{4}^{2-}, \mathrm{HWO}_{4}^{-}, \mathrm{H}_{2} \mathrm{WO}_{4}$ & \multirow{3}{*}{$\begin{array}{c}\left(\mathrm{WO}_{4}\right)(\mathrm{HCit}) \mathrm{H}^{4-},\left(\mathrm{WO}_{4}\right)(\mathrm{HCit}) \mathrm{H}_{2}{ }^{4-} \\
\left(\mathrm{WO}_{4}\right)(\mathrm{HCit}) \mathrm{H}_{3}{ }^{2-},\left(\mathrm{WO}_{4}\right)_{2}(\mathrm{HCit})_{2} \mathrm{H}_{5}{ }^{{ }^{\prime}-} \\
\left(\mathrm{WO}_{4}\right)_{2}(\mathrm{HCit}) \mathrm{H}_{4}{ }^{3-}\end{array}$} \\
\hline Fe(II) Species: & \\
\hline $\begin{array}{c}\mathrm{Fe}^{2+}, \mathrm{Fe}(\mathrm{OH})^{+}, \mathrm{Fe}(\mathrm{OH})_{2}, \mathrm{Fe}(\mathrm{OH})_{3}{ }^{-} \\
\mathrm{Fe}^{2+}: \mathrm{SO}_{4}{ }^{2-} \text { (ionic pairs), } \\
\mathrm{FeCit}^{2-}, \mathrm{FeHCit}^{-}, \mathrm{FeHCitH}, \mathrm{FeHCitH}{ }^{+} \\
\mathrm{Fe}(\mathrm{HCit})_{2}{ }^{4-}, \mathrm{Fe}(\mathrm{HCit})_{2} \mathrm{H}^{3-}\end{array}$ & \\
\hline
\end{tabular}

As can be noticed from Figure 1, the most significant part of Fe(II) and W(VI) are in various citrate complexes, whereas $\mathrm{Fe}(\mathrm{III})$ is mainly in a neutral compound such as $\mathrm{Fe}(\mathrm{OH})_{3}$. Notably, the concentration of free $\mathrm{Fe}^{3+}$ is below the limiting concentration in the saturated solution; therefore, the solubility product of $\left[\mathrm{Fe}^{3+}\right]\left[\mathrm{OH}^{-}\right]$did not reach the limiting value $L_{\mathrm{Fe}(\mathrm{OH})_{3}}=7.4 \times 10^{-36}$, and the solution remains thermodynamically stable. After adding sodium tungstate, the redistribution of citrate complexes occurs and concentrations of potential-determining ions $\mathrm{Fe}^{2+}, \mathrm{Fe}^{3+}$, and $\mathrm{WO}_{4}{ }^{2-}$ increase. Therefore, the Nernst potentials of Fe and $\mathrm{W}$ in the solutions become more negative (see Table 2). 

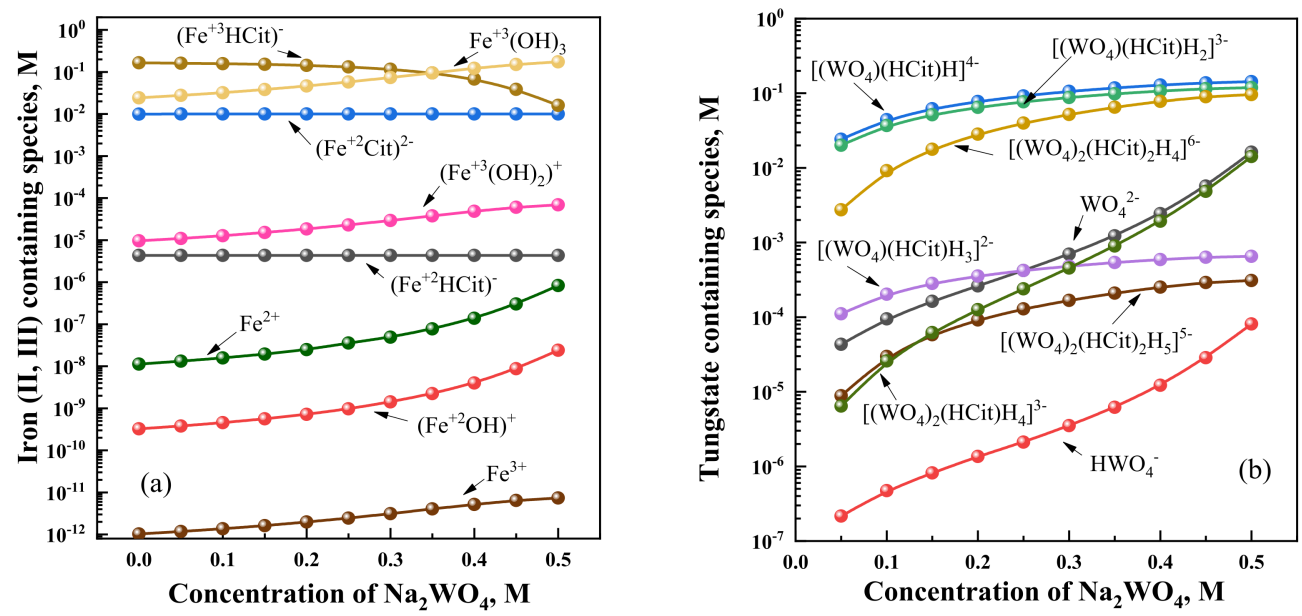

Figure 1. The calculated reversible distribution of main species containing iron (II, III) (a) and tungstate (b). The oxidation state of Fe is marked in the corresponding formula. Calculations were made for the following salt concentrations: iron (II) sulfate $(0.2 \mathrm{M})$, citric acid + sodium citrate $(0.5 \mathrm{M})$, and sodium tungstate $(0.0$ to $0.5 \mathrm{M})$ at $\mathrm{pH} 6.9$.

Table 2. Calculated Nernst potentials as a function of sodium tungstate concentration. Concentrations of $\mathrm{Fe}^{2+}, \mathrm{Fe}^{3+}$ and $\mathrm{WO}_{4}{ }^{2-}$ ions were taken from Figure 1 . The standard reduction potentials (vs $\mathrm{Ag} / \mathrm{AgCl}$ ) were used for calculations: $E_{\mathrm{Fe}^{2+} / \mathrm{Fe}}^{0}=-0.64 \mathrm{~V} ; E^{0}{ }_{\mathrm{WO}_{4}^{2-} / \mathrm{W}}=-1.26 \mathrm{~V}, E^{0} \mathrm{Fe}^{3+} / \mathrm{Fe}^{2+}=0.771 \mathrm{~V}$.

\begin{tabular}{cccc}
\hline \multirow{2}{*}{ Concentration of $\mathrm{Na}_{2} \mathrm{WO}_{4}, \mathbf{M}$} & \multicolumn{3}{c}{ Nernst Potentials of Systems vs. Ag/AgCl Electrode } \\
\cline { 2 - 4 } & $E_{\mathrm{Fe}^{2+} / \mathrm{Fe}^{\prime}}, \mathbf{V}$ & $E_{\mathbf{W O}_{4}^{2-} / \mathbf{W}^{\prime}} \mathbf{V}$ & $E_{\mathbf{F e}^{3+} / \mathrm{Fe}^{2+}, \mathbf{V}}$ \\
\hline- & -0.875 & - & 0.331 \\
\hline 0.05 & -0.873 & -0.680 & 0.331 \\
\hline 0.10 & -0.871 & -0.677 & 0.330 \\
\hline 0.15 & -0.868 & -0.675 & 0.329 \\
\hline 0.20 & -0.865 & -0.673 & 0.328 \\
\hline 0.25 & -0.860 & -0.671 & 0.324 \\
\hline 0.30 & -0.856 & -0.668 & 0.322 \\
\hline 0.35 & -0.850 & -0.666 & 0.317 \\
\hline 0.40 & -0.843 & -0.663 & 0.308 \\
\hline 0.45 & -0.833 & -0.659 & 0.294 \\
\hline 0.50 & -0.820 & -0.655 & 0.271 \\
\hline
\end{tabular}

\subsection{Electrode Processes on Pt-Electrode Below Potentials of Metallic Phase Forming}

Nernst potentials of metals can be considered as a most positive cathodic potential of electrode process resulting in obtaining metallic deposits. The electrodeposition of Fe-W alloy undergoes via the induced codeposition mechanism, as W does not deposit without Fe. Thus, the alloy can be formed at potentials more negative than Nernst potential for Fe in the corresponding solution, i.e., at least $-0.87 \mathrm{~V}$ (all values for investigated solutions are presented in Table 1).

The OCP of Pt in the investigated solutions was $-0.2 \mathrm{~V}$ to $0.0 \mathrm{~V}$ (vs. $\mathrm{Ag} / \mathrm{AgCl}$ ), which is more positive than the Nernst potential of Fe and W. However, it was noticed that the relatively high cathodic current passes (Figure 2a) without sufficient mass gain on the electrode up to potentials close to $-1.0 \mathrm{~V}$. Furthermore, during a potential scan in the opposite direction, Fe-containing deposit remains almost undissolved (rusty deposit remains on the electrode), and the mass of deposit remains unchanged (see Figure 2b). 

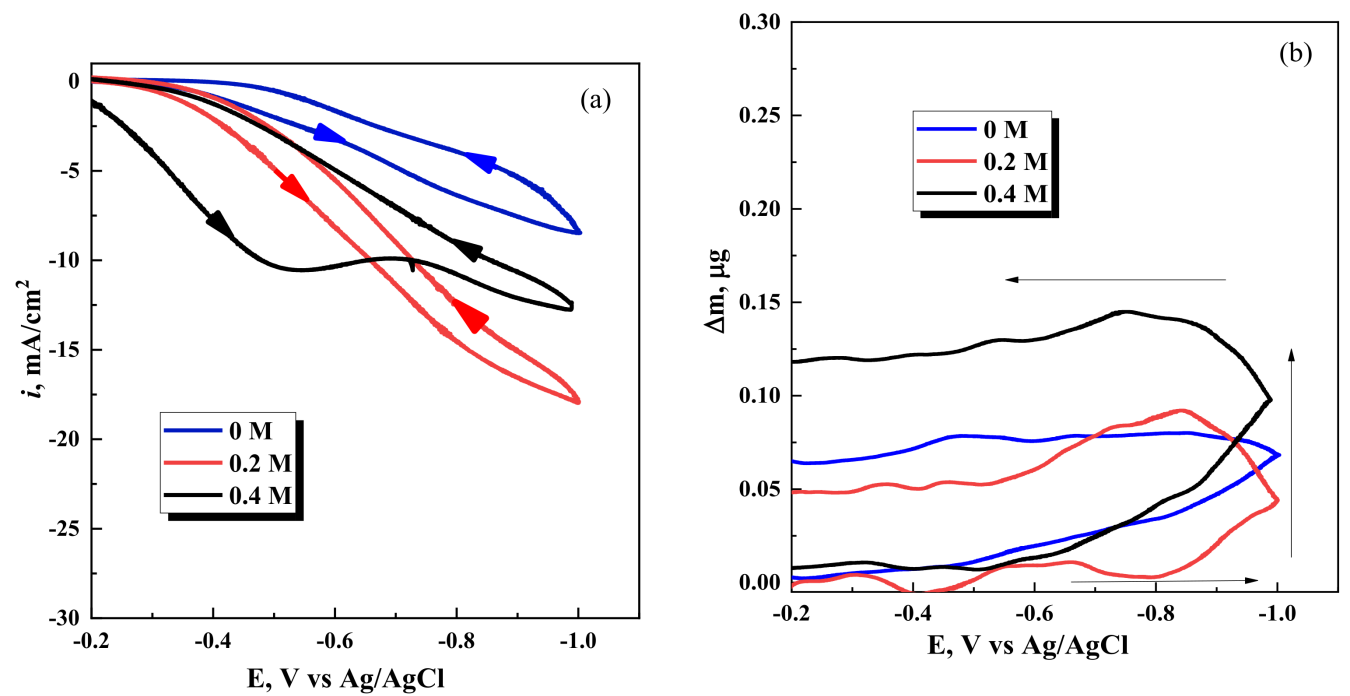

Figure 2. Effects of $\mathrm{Na}_{2} \mathrm{WO}_{4}$ concentrations in the solution on (a) cyclic voltammograms scans, and (b) microgravimetry scans on the Pt electrode. Potential scan rate $20 \mathrm{mV} / \mathrm{s}$; arrows indicate the direction of potential scans.

After the addition of $\mathrm{Na}_{2} \mathrm{WO}_{4}$ into the solution, the registered current density and the mass gain slightly increased, especially at the sodium tungstate concentration $0.4 \mathrm{M}$. However, it still remained rather low, i.e., $<0.75 \mu \mathrm{g} / \mathrm{cm}^{2}$. The codeposition of Fe-W alloys includes the six-electron transfer needed for $\mathrm{W}(\mathrm{VI})$ electroreduction, which occurs via the numbers of intermediate stages involving homogeneous or/and heterogeneous reactions discussed elsewhere [1,2]. During these intermediate stages, adsorbed layers might be formed [31]. The formation of an adsorbed layer below the potential of metallic phase formation can be directly attributed to the mentioned minor mass gain on the microgravimetry scans (Figure 2b). Furthermore, as this mass gain depends on sodium tungstate concentration in the solution, it is most likely that the adsorbed layers include reduced intermediates. If presume that the average molecular weight of adsorbed intermediates (complexes of $\mathrm{W}(\mathrm{II}-\mathrm{VI})$ and $\mathrm{Fe}(\mathrm{II}-\mathrm{III})$ ) on the cathode can be above $400 \mathrm{~g} / \mathrm{mol}$ and use the value of gained mass on the electrode $\left(0.75 \mu \mathrm{g} / \mathrm{cm}^{2}\right)$, we obtain the value $2 \times 10^{-9} \mathrm{~mol} / \mathrm{cm}^{2}$, which is a typical value corresponding to an adsorbed material on the electrodes. In addition, it is particularly interesting to underline, that the formation of such adsorbed layers is irreversible, and during potential scan in the opposite direction, formed layers do not desorb (Figure $2 \mathrm{~b}$ ). The adsorbed layers may consist of partially reduced electrochemically active species such as $\left[\left(\mathrm{WO}_{4}\right)(\mathrm{HCit})(\mathrm{H})\right]^{4-}[32], \mathrm{FeOH}^{+}$and Fe-Cit [39], also of $\left(\mathrm{Fe}(\mathrm{OH})_{2}\right)^{+}$. In addition, during Ni-W electrodeposition, a thin, highly textured film of nonstoichiometric $\mathrm{NiWO}_{4}$ was formed during the codeposition of nickel and tungsten [40]. In the case of the codeposition of $\mathrm{Fe}$ and $\mathrm{W}$, a sparingly soluble $\mathrm{FeWO}_{4}$ can also form, and this compound can be stable [41].

Furthermore, potentiostatic depositions in the potential range $-0.7 \mathrm{~V}--1.05 \mathrm{~V}$ from the investigated electrolytes reveal a similar picture: rather high cathodic current densities (Figure 3a) without metallic phase formation, i.e., current efficiency is close to zero (see Figure $3 \mathrm{~b}$ ). The charge-transfer reactions without mass gain in this range of potentials might be attributed to the hydrogen evolution and the reduction of dissolved oxygen. In addition, an essential amount of Fe(III) is present in the solution, and readily reduces to $\mathrm{Fe}(\mathrm{II})$ at potentials more negative than $0.27-0.33 \mathrm{~V}$. In addition, citrates can undergo various charge transfer reactions at the Pt cathode, modifying the surface by forming of some polymeric species that have been identified [25]. 

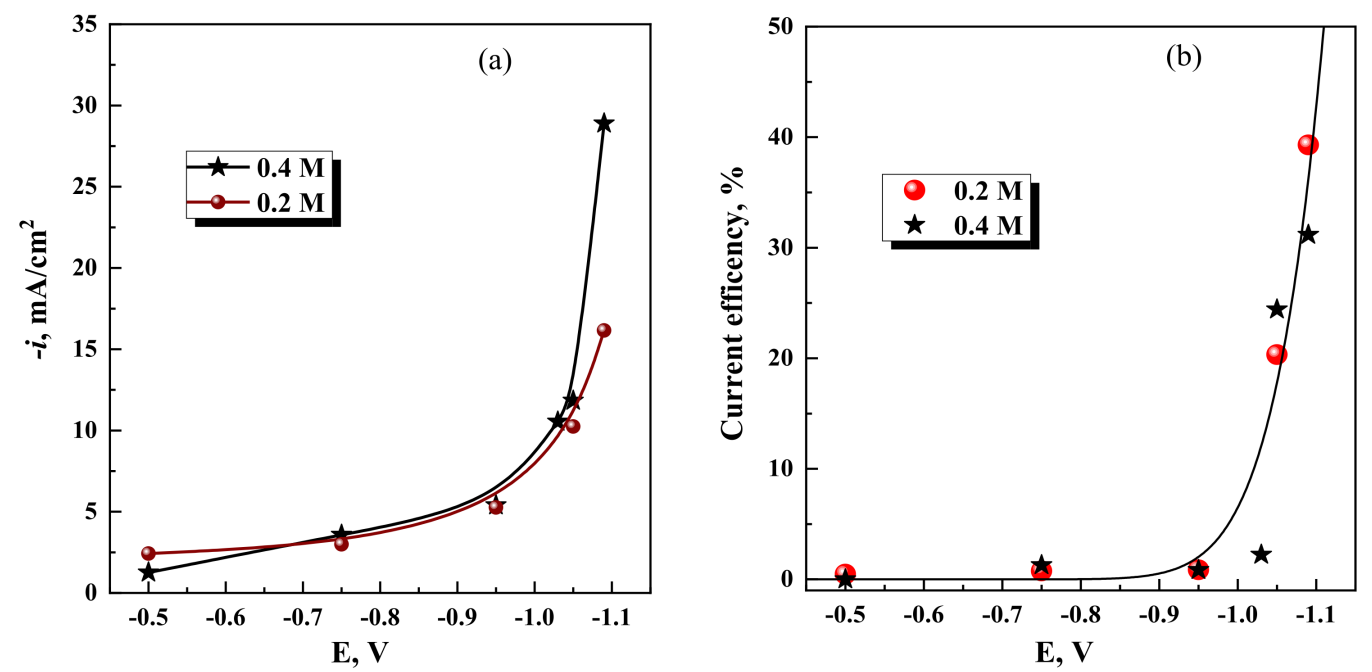

Figure 3. Influence of electrode potential on current density (a), and current efficiency for Fe-W electrodeposition (b) at various $\mathrm{Na}_{2} \mathrm{WO}_{4}$ concentrations on the stationary $\mathrm{Cu}$ electrode.

In order to understand the nature of the electrode processes observed below the potential of metallic phase formation, hydrodynamic controlled depositions were carried out on a rotating disk electrode. The total current density at RDE remains constant (see Figure 4a). However, the occurrence of at least three aforementioned parallel chargetransfer reactions (hydrogen evolution, oxygen reduction, $\mathrm{Fe}(\mathrm{III}) L+e^{-} \rightarrow \mathrm{Fe}(\mathrm{II}) L$, and adsorption of intermediates) results in an unpredictable and abnormal dependence of current density on the rotation frequency of RDE at potentials below thermodynamic availability of electrodeposition of metallic Fe and W (Figure $4 \mathrm{~b}$ ). This phenomenon needs further investigations, which is beyond the scope of this study.
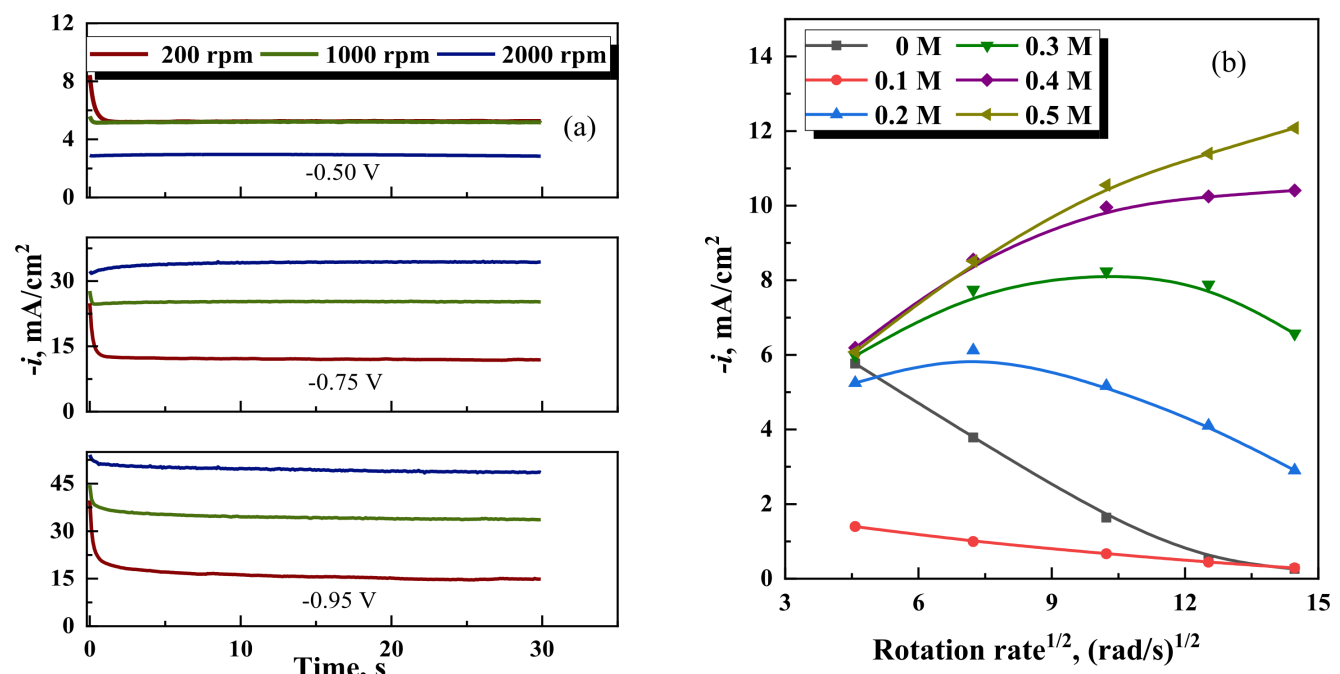

Figure 4. Cont. 


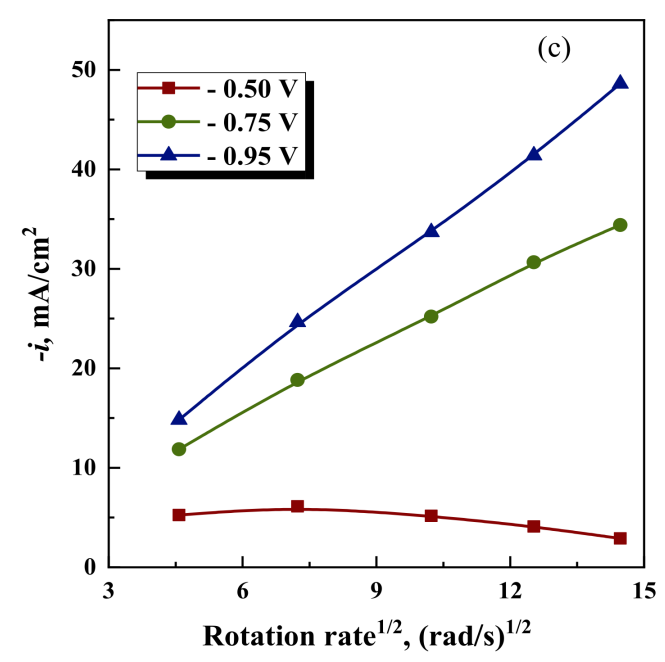

Figure 4. Cathodic current density vs time, at various deposition potentials and rotation rates at $0.2 \mathrm{M}$ $\mathrm{Na}_{2} \mathrm{WO}_{4}(\mathbf{a})$; Levich plots obtained: for various $\mathrm{Na}_{2} \mathrm{WO}_{4}$ concentrations at constant $E=-0.5 \mathrm{~V}$ (b); and various potentials at $0.2 \mathrm{M} \mathrm{Na}_{2} \mathrm{WO}_{4}$ concentration (c).

However, as it was shown in [42], similar dependencies can occur in the presence of intermediates forming during homogeneous chemical reactions. In addition, at potentials $-0.75 \mathrm{~V}$ and $-0.95 \mathrm{~V}$, the total current as a function of rotation speed is closer to linear Levich dependence (see Figure 4c), which confirms that the diffusion-limiting process can occur. This can likely be linked with the partial reduction of $\mathrm{W}(\mathrm{VI}) \mathrm{L}$ to $\mathrm{W}(\mathrm{V}-\mathrm{II})$ catalyzed by $\mathrm{Fe}(\mathrm{II})$ and $\mathrm{Fe}(\mathrm{III})$ compounds.

\subsection{Fe-W Alloy Formation on Pt Electrode}

The cathodic current density and the mass of deposits begins to increase sharply at the potentials higher than $-1.0 \mathrm{~V}$, i.e., above thermodynamic availability of electrodeposition of Fe-W alloys (Figure 5). Both of these parameters increase with increase of concentration of $\mathrm{Na}_{2} \mathrm{WO}_{4}$ in the solution. Once the potential scan direction is reversed, the cathodic current is still observed for potentials $-0.8--0.6 \mathrm{~V}$ (Figure $5 \mathrm{a}$ ), whereas the mass of deposit remains constant up to potential $-0.7 \mathrm{~V}$ (Figure $5 \mathrm{~b}$ ), and then decreases sharply up to zero.
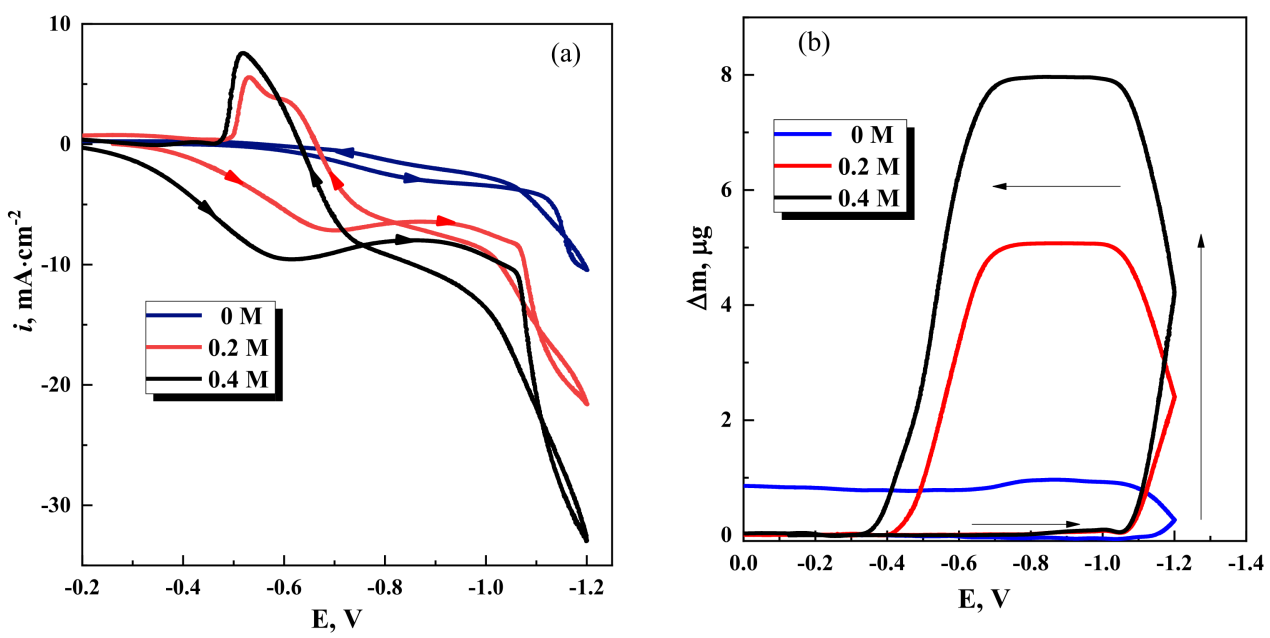

Figure 5. Cyclic voltammograms (a) and microgravimetry scans (b) obtained on $\mathrm{Pt}$ at various $\mathrm{Na}_{2} \mathrm{WO}_{4}$ concentrations in the solution. Potential scan rate $20 \mathrm{mV} / \mathrm{s}$; arrows indicate the direction of potential scans. 
These results could be explained in a following way. The electrocrystallization of the coating comprises slow nucleation stages (either 2D or 3D) due to Fe-W deposition on the Pt substrate. Therefore, as soon as a number of nucleation centers are formed, the formation of the alloy phase starts at potential more negative than $-1.05 \mathrm{~V}$. At the same time, a crossover is showed on voltammograms at about -1.1 V (Figure 5a). Such a shape of voltammogram is regular for slow three-dimensional nucleation onto foreign substrate (Pt in this case) during electrodeposition [43].

Once the potential scan direction is reversed at $-1.2 \mathrm{~V}$ (Figure $5 \mathrm{~b}$ ), the electrodeposition continues on the formed Fe-W alloy layer, and mass is growing up to potential $-1.0 \mathrm{~V}$, and then remains constant up to $-0.75 \mathrm{~V}$. Moreover, at potentials more positive than $-0.75 \mathrm{~V}$, the cathodic current passes (Figure 5a), but the mass of deposit sharply decreases (Figure 5b). Notably, on a voltammogram, the overall passed current is represented as a sum of partial currents of all charge-transfer reactions (including side reactions) occurring on the electrode. Thus, at potentials more positive than $-0.75 \mathrm{~V}$ (see Figure $5 \mathrm{a}$ ), the dissolution of Fe-W should start (according to Nernst potentials for Fe and W), and indeed the mass decrease is noted (Figure $5 b$ ). However, the anodic current on CV is not present because the anodic current component is overrun by the cathodic current components of the side reactions (Figure 5a). It should be noted that the dissolution potential for alloy can shift from the Nernst potentials of alloy's component. Suppose the binary system forms a stable solid solution. In that case, the positive shift in equilibrium potential can be significant [44], resulting in the dissolution of Fe-W at more positive potentials than Fe.

Further investigations of RDE at the potential $-1.05 \mathrm{~V}$ shows that the current density of the overall electrode process increases with increasing rotation speed and concentration of $\mathrm{Na}_{2} \mathrm{WO}_{4}$ in the solution (see Figure 6a). Notably, the electrode process in such case may be described using formalities of mixed kinetics (activation control plus diffusion), because the dependencies in Koutecky-Levich coordinates are linear (see Figure $6 \mathrm{~b}, \mathrm{c}$ ). On the other hand, the electrode process in this range of potentials consists of few charge-transfer reactions (reduction of $\mathrm{Fe}, \mathrm{W}$, side reactions-hydrogen evolution, oxygen reduction). Thus, the current efficiency for Fe-W electrodeposition does not exceed $40 \%$ (see Figure 3 ). Therefore, the extrapolation to zero, in this case, gives the apparent values of "kinetic current" (in $1 / i_{k}$ ) and "diffusion current". Remarkably, both formal kinetic current and diffusion current of the overall cathodic process linearly depend on the concentration of $\mathrm{Na}_{2} \mathrm{WO}_{4}$ in the potential range where Fe-W formation occurs. Whereas, in the potential range below of thermodynamic formation of Fe-W alloy, these currents are independent on the concentration of $\mathrm{Na}_{2} \mathrm{WO}_{4}$ in the solution (see Figure 7).
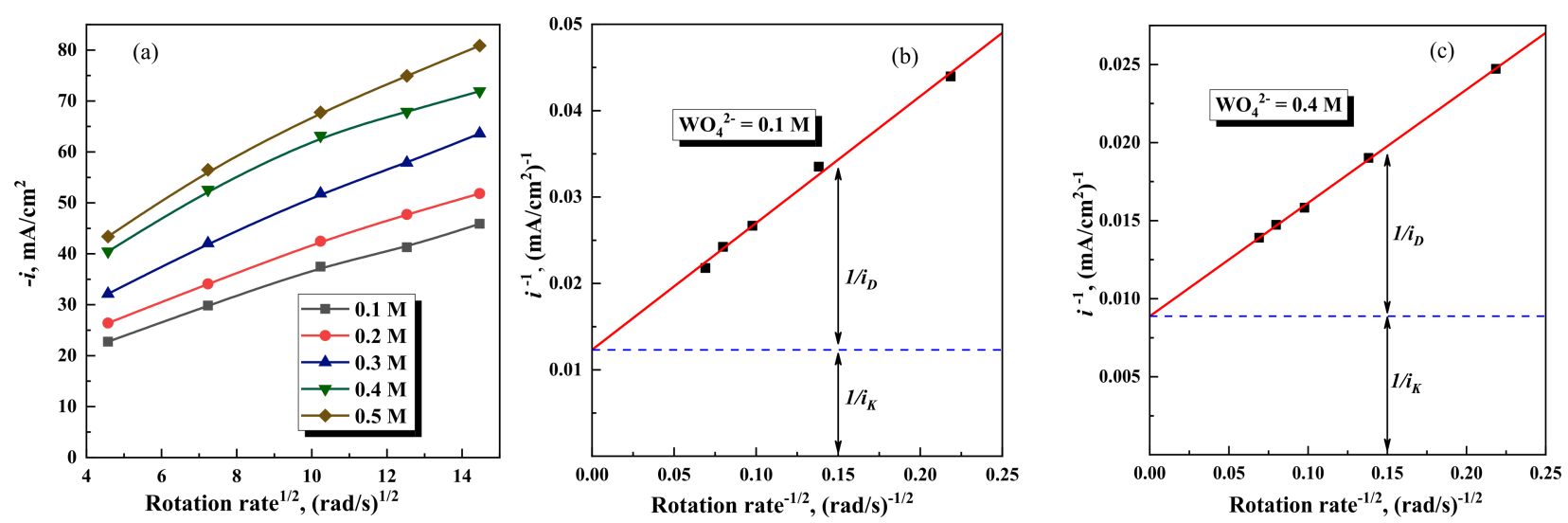

Figure 6. Levich plots were obtained for various concentrations of $\mathrm{Na}_{2} \mathrm{WO}_{4}(\mathbf{a})$, and Koutecky-Levich plots for indicated concentrations of $\mathrm{Na}_{2} \mathrm{WO}_{4}(\mathbf{b}, \mathbf{c})$. All presented data were obtained at $E=-1.05 \mathrm{~V}$. 

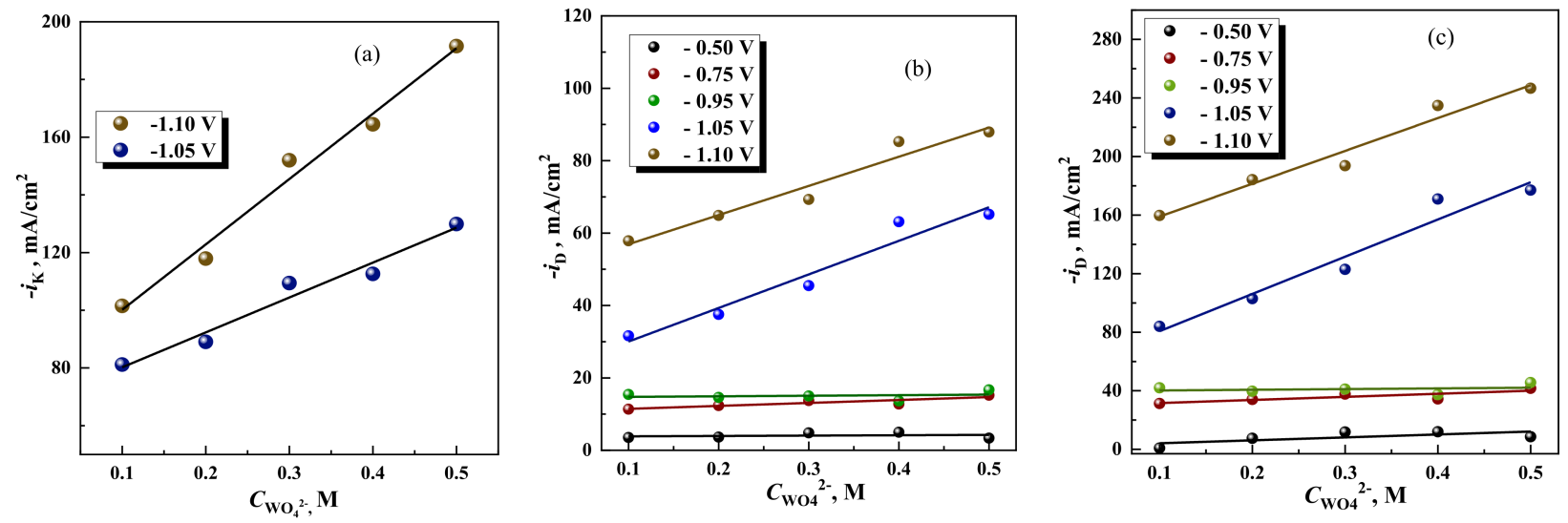

Figure 7. The effect of $\mathrm{Na}_{2} \mathrm{WO}_{4}$ concentration on kinetic current densities (a), and diffusion current densities for $200 \mathrm{rpm}$ (b); $1500 \mathrm{rpm}(\mathrm{c})$.

During codeposition of $\mathrm{Fe}$ and $\mathrm{W}$, the partial currents of electrode reactions and content of $\mathrm{W}$ in the Fe-W alloys change with concentration of $\mathrm{Na}_{2} \mathrm{WO}_{4}$ as well (see data presented in Table 3). At the deposition potential $-1.05 \mathrm{~V}$ (vs. $\mathrm{Ag} / \mathrm{AgCl}$ ), the increase of $\mathrm{Na}_{2} \mathrm{WO}_{4}$ from $0.2 \mathrm{M}$ to $0.4 \mathrm{M}$ leads to a rise of the $\mathrm{W}$ content from 15.9 at. $\%$ to 26.0 at. $\%$ and partial currents for $\mathrm{W}$ and $\mathrm{Fe} \sim 5$ and $\sim 3$ times, respectively. The partial current of some components commonly depends on the concentration of electrochemically active complex (EAC) in the solution. In our opinion, for $\mathrm{W}$ the role of EAC, in addition to $\left[\left(\mathrm{WO}_{4}\right)(\mathrm{HCit})(\mathrm{H})\right]^{4-}$, may play other tungstate-citrate complexes such as $\left[\left(\mathrm{WO}_{4}\right)_{2}(\mathrm{HCit}) \mathrm{H}_{4}\right]^{3-}$.

Table 3. Dependence of concentration of tungsten in the Fe-W coatings (at.\%) and partial current densities on the concentration of $\mathrm{Na}_{2} \mathrm{WO}_{4}$ in the electrolyte and applied cathodic potential (deposition time $\sim 1 \mathrm{~h}$ ).

\begin{tabular}{cccccc}
\hline \multirow{2}{*}{$-\mathrm{E}, \mathbf{V}$} & \multirow{2}{*}{$\begin{array}{c}\text { Concentration of } \mathbf{N a}_{\mathbf{2}} \mathbf{W O}_{\mathbf{4}} \\
\text { in the Solution, } \mathbf{M}\end{array}$} & $\begin{array}{c}\text { Concentration of } \mathbf{W} \\
\text { in the Alloy, at.\% }\end{array}$ & \multicolumn{3}{c}{$\begin{array}{c}\text { Partial Current Density, } \\
\mathbf{m A} / \mathbf{c m}^{2}\end{array}$} \\
\cline { 4 - 7 } & 0.2 & 15.9 & $\mathbf{W}$ & $\mathbf{F e}$ & Side Reaction \\
\cline { 2 - 6 } 1.05 & 0.4 & 26.0 & 1.47 & 5.02 & 9.75 \\
\hline \multirow{2}{*}{1.10} & 0.2 & 22.6 & 0.75 & 2.14 & 8.96 \\
\cline { 2 - 6 } & 0.4 & 27.1 & 2.44 & 6.56 & 19.89 \\
\hline
\end{tabular}

The possibility for a few different species to act as EAC was discussed in [39]. As it was shown in Figure 1, with the increase in concentration of sodium tungstate in the solution from 0.2 to $0.4 \mathrm{M}$, the concentrations of the $\left[\left(\mathrm{WO}_{4}\right)(\mathrm{HCit})(\mathrm{H})\right]^{4-}$ and $\left[\left(\mathrm{WO}_{4}\right)_{2}(\mathrm{HCit}) \mathrm{H}_{4}\right]^{3-}$ increase 1.7 and 15 times, respectively. Simultaneously, with an increase in concentration of sodium tungstate and formation of tungstate-citrate complexes, redistribution of complexes takes place and concentration of EAC, which can lead to iron deposition, also increases. Thus, the concentration of $\mathrm{FeOH}^{+}$species increases $\sim 5$ times with a rising concentration of sodium tungstate. Taking into account that EAC in the course of charge-transfer reaction forms adsorbed intermediates and the rate of heterogeneous reactions depends both on concentration in the solution and degree of surface coverage, the increase in partial currents might not have linear dependence on the concentration of species. Accordingly, the composition of alloys changes slightly at the potential $-1.1 \mathrm{~V}$ (Table 3), but partial currents for $\mathrm{W}$ and Fe increase $\sim 3$ times with a change in sodium tungstate concentration from 0.2 to $0.4 \mathrm{M}$.

These data can suggest that the formation of Fe-W alloy is occurring due to an autocatalytic reaction probably via the formation of mixed adsorbed species containing $\mathrm{Fe}$ and $\mathrm{W}$ compounds or nucleation clusters containing both metals on the electrode surface. The role 
of heterogeneous reactions might be strengthened by the fact that content of $\mathrm{W}$ in $\mathrm{Fe}-\mathrm{W}$ alloys approaches to the limiting value: to 27 at.\% in the citrate bath, and to $33-35$ at. $\%$ in the citrate-ammonium solution when the surface is covered by adsorbed intermediates in large degree [45]. The peculiarities of side reactions in this range of potentials are governed mainly by hydrogen evolution reactions on Fe-W having various compositions.

\subsection{Interdependences at Induced Codeposition and Applicability of Fe-W Alloys}

As discussed above, the interplay between bath parameters, electrode reactions and applied potential (current) certainly will affect the properties of desired materials and their application. Thus, as clearly shown by the EQCM, the strong adsorption of species on the electrode will have a great impact, e.g., on size effects appearance (dependence of microhardness, corrosion rate on dimensions of the depositing area/bath) and incorporation of light elements mentioned above. This spotlights an apparent requirement to control potential and bath composition in order to achieve targeted materials and subsequent applications. One of the important outcomes of the presented findings, namely the dissolution of Fe-W under total cathodic current (see Figure 5), may be useful for the pulse deposition of alloys on complex surfaces. Commonly, complex surfaces have different deposition/dissolution rates depending on the geometry of the surfaces. Therefore, it is possible to obtain more uniform deposits containing fewer inclusions of adsorbed compounds (such as carbon, oxides) by varying only cathodic potential in pulse deposition mode.

Moreover, based on the knowledge of bath chemistry, potentials of alloy formation and interdependencies of partial currents for $\mathrm{Fe}, \mathrm{W}$ and side reactions, the smart options are created by tuning the $\mathrm{W}$ content in Fe-W alloys for various applications, e.g.,:

1. By applying $-1.05 \mathrm{~V}$ and a low concentration of $\mathrm{Na}_{2} \mathrm{WO}_{4}$ in the bath will result in a high deposition rate, but lower tungsten content, which is suitable for magnetic applications.

2. By applying $-1.05 \mathrm{~V}$ coupled with a high concentration of $\mathrm{Na}_{2} \mathrm{WO}_{4}$ will result in a relatively high deposition rate, increased tungsten content in the alloy and a relatively low rate of side reactions. Consequently, fewer defects in the coating due to hydrogen evolution or incorporation of organic compounds will be introduced, which is suitable for protective coatings (wear and corrosion resistant) application.

3. Fe-W alloys obtained at $-1.1 \mathrm{~V}$ and a high concentration of $\mathrm{Na}_{2} \mathrm{WO}_{4}$ in the bath will contain a high amount of $\mathrm{W}$, and therefore are promising candidates to act as cathodes for hydrogen evolution reaction [11].

\section{Conclusions}

1. The effect of sodium tungstate concentration ranged from $0.1 \mathrm{M}$ to $0.5 \mathrm{M}$ on the electrode reactions at Fe-W alloy electrodeposition onto Pt. Analysis of the calculated distribution of species formed by dissolving of $\mathrm{FeSO}_{4}, \mathrm{Na}_{2} \mathrm{WO}_{4}$, citric acid and sodium tri-citrate shows that at least 29 particles are formed involving $\mathrm{Fe}(\mathrm{II})$ and $\mathrm{Fe}(\mathrm{III})$ complexes with hydroxo- and citrate- groups in mixed $\mathrm{WO}_{4}$-citrate complexes. Therefore, the Nernst potentials of Fe and $W$ are shifted essentially from standard values, and the formation of alloys becomes thermodynamically possible at potentials less than $-0.87 \mathrm{~V}$ to $-0.82 \mathrm{~V}$ ( $\mathrm{vs}$. $\mathrm{Ag} / \mathrm{AgCl}$ ) dependently on the concentration of sodium tungstate in the solution.

2. The relatively high cathodic current is passed without sufficient mass gain on Pt electrode $\left(\sim 0.75 \mu \mathrm{g} / \mathrm{cm}^{2}\right)$ up to cathodic potentials close to $-1.0 \mathrm{~V}$. Such small mass gains $\left(\sim 2 \times 10^{-9} \mathrm{~mol} / \mathrm{cm}^{2}\right)$ might be attributed to the formation of adsorbed intermediates comprising tungsten species of various oxidation states. In addition, there were at least three charge-transfer reactions, which can occur on the electrode without mass gain. These reactions and adsorption of intermediates result in an unpredictable and abnormal dependence of current density on the rotation rate of RDE at potentials below thermodynamic availability of the electrodeposition of metallic Fe and W. 
3. For the first time, the decrease in electrode mass during the cathodic current pass in the course of $\mathrm{CV}$ recording was detected by the electrochemical microbalance technique. It was explained by the appearance of a partial anodic dissolution current for Fe-W component of overall current in the potential range between $\mathrm{OCP}$ of $\mathrm{Pt}$ in the solution and potentials below thermodynamic stability of $\mathrm{Fe}-\mathrm{W}$ in the studied solutions (i.e., less than $-0.80 \mathrm{~V}$ ). This anodic component of the total current is counterbalanced by occurring cathodic side reactions. The crossovers presenting on the cyclic voltammograms at potentials approx. $-1.1 \mathrm{~V}$ indicates a slow threedimensional Fe-W nucleation on Pt during electrodeposition at potentials less than the thermodynamic possibility of Fe-W formation.

4. The electrode process involving Fe-W alloy formation may be described using formalities of mixed kinetics (activation control plus diffusion). As the overall electrode process consists of few charge-transfer reactions (reduction of Fe and $\mathrm{W}$, side reactions such as hydrogen evolution, oxygen reduction), the current efficiency does not exceed $40 \%$ for Fe-W electrodeposition. Therefore, the determined values of kinetic current and diffusion current of electrode process by RDE are apparent. Both apparent kinetic and diffusion currents of the overall cathodic process linearly depend on the concentration of $\mathrm{Na}_{2} \mathrm{WO}_{4}$ in the potential range where the formation of $\mathrm{Fe}-\mathrm{W}$ occurs. However, the partial currents for both $\mathrm{W}$ and Fe increased threefold with the twofold increase of sodium tungstate concentration. It is presumed that the codeposition of Fe-W alloy is occurring due to an autocatalytic reaction, likely via the formation of mixed adsorbed species containing Fe and $\mathrm{W}$ compounds or nucleation clusters containing both metals on the electrode surface.

Author Contributions: Investigation, S.B. and S.S.; Methodology, A.D. and H.C.; Visualization, N.T.; Writing-Original Draft Preparation, A.D., H.C. and N.T.; Writing-Review \& Editing, H.C. and N.T. All authors have read and agreed to the published version of the manuscript.

Funding: This research has received funding from Horizon 2020 research and innovation program under MSCA-RISE-2017 (No. 778357).

Institutional Review Board Statement: Not applicable.

Informed Consent Statement: Not applicable.

Data Availability Statement: Not applicable.

Conflicts of Interest: The authors declare no conflict of interest.

\section{References}

1. Eliaz, N.; Gileadi, E. Induced Codeposition of Alloys of Tungsten, Molybdenum and Rhenium with Transition Metals. In Modern Aspects of Electrochemistry; Vayenas, C.G., White, R.E., Gamboa-Aldeco, M.E., Eds.; Springer: New York, NY, USA, 2008; Volume 42, pp. 191-301. ISBN 978-0-387-49488-3.

2. Tsyntsaru, N.; Cesiulis, H.; Donten, M.; Sort, J.; Pellicer, E.; Podlaha-Murphy, E.J. Modern Trends in Tungsten Alloys Electrodeposition with Iron Group Metals. Surf. Eng. Appl. Electrochem. 2012, 48, 491-520. [CrossRef]

3. Podlaha, E.J.; Landolt, D. Induced Codeposition: II. A Mathematical Model Describing the Electrodeposition of Ni-Mo Alloys. J. Electrochem. Soc. 1996, 143, 893-899. [CrossRef]

4. Spasojevic, M.; Markovic, D.; Spasojevic, M.; Vukovic, Z.; Maricic, A.; Ribic-Zelenovic, L. Effect of Deposition Current Density and Annealing Temperature on the Microstructure and Magnetic Properties of Nanostructured Ni-Fe-W-Cu Alloys. Sci. Sinter. 2019, 51, 209-221. [CrossRef]

5. Ved, M.V.; Sakhnenko, N.D.; Karakurkchi, A.V.; Pershina, K.D.; Yermolenko, I.Y. Corrosion Properties of Galvanic Fe-Mo(W), Fe-Mo-W Coatings. Funct. Mater. 2019, 26, 534-540. [CrossRef]

6. Cesiulis, H.; Tsytsaru, N.; Podlaha, E.J.; Li, D.; Sort, J. Electrodeposition of Iron-Group Alloys into Nanostructured Oxide Membranes: Synthetic Challenges and Properties. CNANO 2018, 15, 84-99. [CrossRef]

7. Maliar, T.; Cesiulis, H.; Podlaha, E.J. Coupled Electrodeposition of Fe-Co-W Alloys: Thin Films and Nanowires. Front. Chem. 2019, 7, 542. [CrossRef]

8. Nicolenco, A.; Tsyntsaru, N.; Matijošius, T.; Asadauskas, S.; Cesiulis, H. Wear Resistance of Electrodeposited Fe-W Alloy Coatings under Dry Conditions and in the Presence of Rapeseed Oil. Green Tribol. 2018, 1, 16-23. [CrossRef] 
9. Nicolenco, A.; Tsyntsaru, N.; Fornell, J.; Pellicer, E.; Reklaitis, J.; Baltrunas, D.; Cesiulis, H.; Sort, J. Mapping of Magnetic and Mechanical Properties of Fe-W Alloys Electrodeposited from Fe(III)-Based Glycolate-Citrate Bath. Mater. Des. 2018, 139, $429-438$. [CrossRef]

10. Barbano, E.P.; Carlos, I.A.; Vallés, E. Electrochemical Synthesis of Fe-W and Fe-W-P Magnetic Amorphous Films and Fe-W Nanowires. Surf. Coat. Technol. 2017, 324, 80-84. [CrossRef]

11. Vernickaite, E.; Tsyntsaru, N.; Sobczak, K.; Cesiulis, H. Electrodeposited Tungsten-Rich Ni-W, Co-W and Fe-W Cathodes for Efficient Hydrogen Evolution in Alkaline Medium. Electrochim. Acta 2019, 318, 597-606. [CrossRef]

12. Tharamani, C.N.; Beera, P.; Jayaram, V.; Begum, N.S.; Mayanna, S.M. Studies on Electrodeposition of Fe-W Alloys for Fuel Cell Applications. Appl. Surf. Sci. 2006, 253, 2031-2037. [CrossRef]

13. Yar-Mukhamedova, G.; Ved, M.; Sakhnenko, N.; Karakurkchi, A.; Yermolenko, I. Iron Binary and Ternary Coatings with Molybdenum and Tungsten. Appl. Surf. Sci. 2016, 383, 346-352. [CrossRef]

14. Gamburg, Y.D.; Zakharov, E.N. The Effect of Hydrogen on Amorphization of Iron-Tungsten Alloys Produced by Electrochemical Synthesis. Russ. J. Electrochem. 2008, 44, 736-739. [CrossRef]

15. Wang, S.; Zeng, C.; Ling, Y.; Wang, J.; Xu, G. Phase Transformations and Electrochemical Characterizations of Electrodeposited Amorphous Fe-W Coatings. Surf. Coat. Technol. 2016, 286, 36-41. [CrossRef]

16. Dresvyannikov, A.F.; Kolpakov, M.E.; Ermolayeva, E.A. Synthesis and Properties of Dispersed Systems Based on Elemental Iron and Tungsten Obtained through Precipitation on Aluminum in the Presence of Citric Acid. Prot. Met. Phys. Chem. Surf. 2018, 54, 58-62. [CrossRef]

17. Bodaghi, A.; Hosseini, J. Corrosion Resistance and Electrocatalytic Properties of Co-W Alloy Coatings. Surf. Eng. 2012, 28, 632-635. [CrossRef]

18. Sriraman, K.R.; Ganesh Sundara Raman, S.; Seshadri, S.K. Corrosion Behaviour of Electrodeposited Nanocrystalline Ni-W and Ni-Fe-W Alloys. Mater. Sci. Eng. A 2007, 460-461, 39-45. [CrossRef]

19. Younes-Metzler, O.; Zhu, L.; Gileadi, E. The Anomalous Codeposition of Tungsten in the Presence of Nickel. Electrochim. Acta 2003, 48, 2551-2562. [CrossRef]

20. Nicolenco, A.; Tsyntsaru, N.; Cesiulis, H. Fe (III)-Based Ammonia-Free Bath for Electrodeposition of Fe-W Alloys. J. Electrochem. Soc. 2017, 164, D590-D596. [CrossRef]

21. Cruywagen, J.J.; Krüger, L.; Rohwer, E.A. Complexation of Tungsten (VI) with Citrate. J. Chem. Soc. Dalton Trans. 1991, $1727-1731$. [CrossRef]

22. Chang, L.M.; Wang, Z.T.; Shi, S.Y.; Liu, W. Study on Microstructure and Properties of Electrodeposited Ni-W Alloy Coating with Glycolic Acid System. J. Alloys Compd. 2011, 509, 1501-1504. [CrossRef]

23. Belevskii, S.S.; Yushchenko, S.P.; Dikusar, A.I. Anomalous Electrodeposition of Co-W Coatings from a Citrate Electrolyte Due to the Formation of Multinuclear Heterometallic Complexes in the Solution. Surf. Eng. Appl. Electrochem. 2012, 48, 97-98. [CrossRef]

24. Yar-Mukhamedova, G.; Ved', M.; Yermolenko, I.; Sakhnenko, N.; Karakurkchi, A.; Kemelzhanova, A. Effect of Electrodeposition Parameters on the Composition and Surface Topography of Nanostructured Coatings by Tungsten with Iron and Cobalt. Eurasian Chem. Technol. J. 2020, 22, 19. [CrossRef]

25. Berkh, O.; Burstein, L.; Shacham-Diamand, Y.; Gileadi, E. The Chemical and Electrochemical Activity of Citrate on Pt Electrodes. J. Electrochem. Soc. 2011, 158, F85. [CrossRef]

26. Belevskii, S.S.; Danilchuk, V.V.; Gotelyak, A.V.; Lelis, M.; Yushchenko, S.P.; Dikusar, A.I. Electrodeposition of Fe-W Alloys from Citrate Bath: Impact of Anode Material. Surf. Engin. Appl. Electrochem. 2020, 56, 1-12. [CrossRef]

27. Morgan, B.; Lahav, O. The Effect of $\mathrm{pH}$ on the Kinetics of Spontaneous Fe(II) Oxidation by $\mathrm{O}_{2}$ in Aqueous Solution-Basic Principles and a Simple Heuristic Description. Chemosphere 2007, 68, 2080-2084. [CrossRef]

28. Ghaferi, Z.; Sharafi, S.; Bahrololoom, M.E. Effect of Current Density and Bath Composition on Crystalline Structure and Magnetic Properties of Electrodeposited FeCoW Alloy. Appl. Surf. Sci. 2015, 355, 766-773. [CrossRef]

29. Mulone, A.; Nicolenco, A.; Hoffmann, V.; Klement, U.; Tsyntsaru, N.; Cesiulis, H. In-Depth Characterization of as-Deposited and Annealed Fe-W Coatings Electrodeposited from Glycolate-Citrate Plating Bath. Electrochim. Acta 2018, 261, 167-177. [CrossRef]

30. Myrzak, V.; Gotelyak, A.V.; Dikusara, A.I. On the Size Effects of the Coatings Surfaces Properties Obtained at Electrodeposition of Alloys of Iron Group Metals With Tungsten. Electron. Process. Mater. 2020, 56, 1-11. [CrossRef]

31. Belevskii, S.S.; Cesiulis, H.; Tsyntsaru, N.I.; Dikusar, A.I. The Role of Mass Transfer in the Formation of the Composition and Structure of CoW Coatings Electrodeposited from Citrate Solutions. Surf. Engin. Appl.Electrochem. 2010, 46, 570-578. [CrossRef]

32. Beltowska-Lehman, E.; Indyka, P.; Bigos, A.; Szczerba, M.J.; Kot, M. Effect of Hydrodynamic Conditions of Electrodeposition Process on Microstructure and Functional Properties of Ni-W/ZrO2 Nanocomposites. J. Electroanal. Chem. 2016, 775, 27-36. [CrossRef]

33. Kovalska, N.; Pfaffeneder-Kmen, M.; Tsyntsaru, N.; Mann, R.; Cesiulis, H.; Hansal, W.; Kautek, W. The Role of Glycine in the Iron-Phosphorous Alloy Electrodeposition. Electrochim. Acta 2019, 309, 450-459. [CrossRef]

34. Sassi, W.; Dhouibi, L.; Berçot, P.; Rezrazi, M.; Triki, E. Study of the Electroplating Mechanism and Physicochemical Proprieties of Deposited Ni-W-Silicate Composite Alloy. Electrochim. Acta 2014, 117, 443-452. [CrossRef]

35. Izaki, M. Electrodeposition of Iron and Iron Alloys. In Modern Electroplating; Schlesinger, M., Paunovic, M., Eds.; John Wiley \& Sons, Inc.: Hoboken, NJ, USA, 2011; pp. 309-326. ISBN 978-0-470-60263-8. 
36. Adeli, B.; Hydarzadeh Sohi, M.; Mehrizi, S. Effects of Sodium Citrate and Current Density on Electroplated Nanocrystalline Cobalt-Iron Thin Films. Int. J. Mod. Phys. Conf. Ser. 2012, 5, 696-703. [CrossRef]

37. Müller, T.; Grimwood, J.; Bachmaier, A.; Pippan, R. Electrodeposition of Fe-C Alloys from Citrate Baths: Structure, Mechanical Properties, and Thermal Stability. Metals 2018, 8, 363. [CrossRef]

38. Belevskii, S.S.; Gotelyak, A.V.; Yushchenko, S.P.; Dikusar, A.I. Electrodeposition of Nanocrystalline Fe-W Coatings from a Citrate Bath. Surf. Engin. Appl. Electrochem. 2019, 55, 119-129. [CrossRef]

39. Nicolenco, A.; Chen, Y.; Tsyntsaru, N.; Cesiulis, H.; Pellicer, E.; Sort, J. Mechanical, Magnetic and Magnetostrictive Properties of Porous Fe-Ga Films Prepared by Electrodeposition. Mater. Des. 2021, 208, 109915. [CrossRef]

40. Juškènas, R.; Valsiūnas, I.; Pakštas, V.; Selskis, A.; Jasulaitienè, V.; Karpavičienė, V.; Kapočius, V. XRD, XPS and AFM Studies of the Unknown Phase Formed on the Surface during Electrodeposition of Ni-W Alloy. Appl. Surf. Sci. 2006, 253, 1435-1442. [CrossRef]

41. Horner, C. Solubility and Hydrolysis of $\mathrm{FeWO}_{4}$ and $\mathrm{MnWO}_{4}$ in the $25^{\circ}-300{ }^{\circ} \mathrm{C}$ Range, and the Zonation of Wolframite. Chem Geol. 1979, 27, 85-97. [CrossRef]

42. Modestov, A.D.; Konev, D.V.; Antipov, A.E.; Petrov, M.M.; Pichugov, R.D.; Vorotyntsev, M.A. Bromate Electroreduction from Sulfuric Acid Solution at Rotating Disk Electrode: Experimental Study. Electrochim. Acta 2018, 259, 655-663. [CrossRef]

43. Palomar-Pardavé, M.; Ramírez, M.T.; González, I.; Serruya, A.; Scharifker, B.R. Silver Electrocrystallization on Vitreous Carbon from Ammonium Hydroxide Solutions. J. Electrochem. Soc. 1996, 143, 1551-1558. [CrossRef]

44. Zangari, G. Electrodeposition of Alloys and Compounds in the Era of Microelectronics and Energy Conversion Technology. Coatings 2015, 5, 195-218. [CrossRef]

45. Donten, M.; Cesiulis, H.; Stojek, Z. Electrodeposition and Properties of Ni-W, Fe-W and Fe-Ni-W Amorphous Alloys. A Comparative Study. Electrochim. Acta 2000, 45, 3389-3396. [CrossRef] 